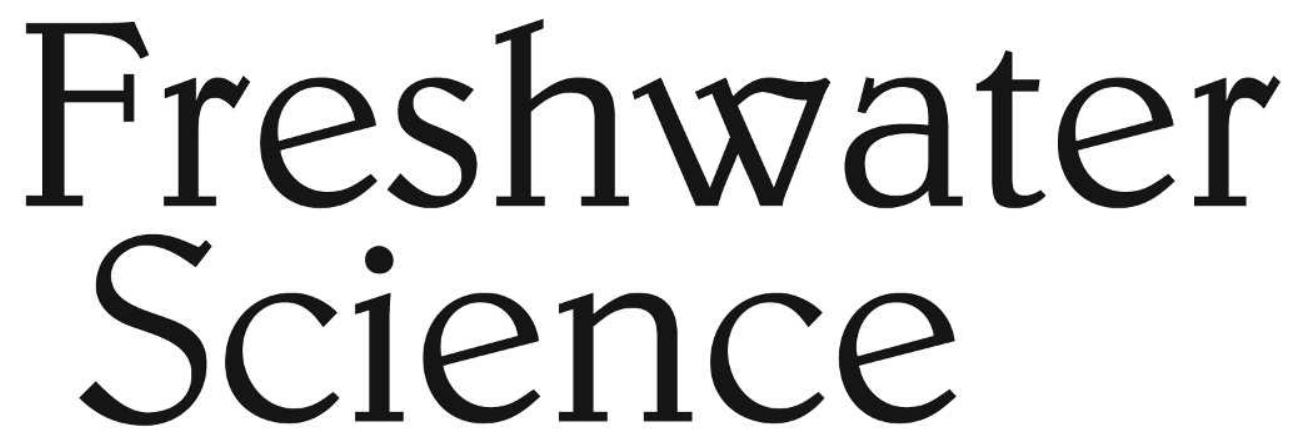

(Formerly the Journal of the North American Benthological Society)

Benthic organic carbon release stimulates bacterioplankton production in a clear-water subarctic lake

Patricia Rodríguez ${ }^{1,4}$, Jenny Ask ${ }^{2,5}$, Catherine L. Hein ${ }^{3,6}$, Mats Jansson ${ }^{1,7}$, AND Jan Karlsson ${ }^{3,8}$

${ }^{1}$ Department of Ecology, Genetics and Evolution, School of Exact and Natural Sciences, University of Buenos Aires, C1428EHA, Argentina

${ }^{2}$ Department of Ecology and Environmental Science, Umeå University, 90187 Umeå, Sweden

${ }^{3}$ Climate Impacts Research Centre (CIRC), Department of Ecology and Environmental Science,

Umeå University, Box 62, 98107 Abisko, Sweden 


\title{
Benthic organic carbon release stimulates bacterioplankton production in a clear-water subarctic lake
}

\author{
Patricia Rodríguez ${ }^{1,4}$, Jenny Ask ${ }^{2,5}$, Catherine L. Hein ${ }^{3,6}$, Mats Jansson ${ }^{1,7}$, \\ AND Jan Karlsson ${ }^{3,8}$ \\ ${ }^{1}$ Department of Ecology, Genetics and Evolution, School of Exact and Natural Sciences, University of \\ Buenos Aires, C1428EHA, Argentina \\ ${ }^{2}$ Department of Ecology and Environmental Science, Umeå University, 90187 Umeå, Sweden \\ ${ }^{3}$ Climate Impacts Research Centre (CIRC), Department of Ecology and Environmental Science, \\ Umeå University, Box 62, 98107 Abisko, Sweden
}

\begin{abstract}
We carried out a set of experiments in a small clear-water lake in northern Sweden during summer 2010 to assess the effect of organic C (OC) released from epipelic algae on pelagic bacterial production (BP). The release rate of OC (dissolved and particulate) from epipelic algae was $\sim 45.4 \mathrm{ng} C$ $\mathrm{m}^{-2} \mathrm{~h}^{-1}$. Bacterioplankton uptake of dissolved OC was P-limited, and pelagic primary production (PP) was colimited by $\mathrm{N}$ and P. Pelagic BP $\left(3.2 \pm 6 \mu \mathrm{g} \mathrm{C} \mathrm{L}^{-1} \mathrm{~h}^{-1}\right)$ exceeded pelagic PP $(0.012 \pm 0.008 \mu \mathrm{g} \mathrm{C}$ $\left.\mathrm{L}^{-1} \mathrm{~h}^{-1}\right)$. Pelagic BP was higher in lake water in contact with sediments and the epipelic algae growing on their surface than in water separated from the sediments. Epipelic algae release OC to lake water and potentially stimulate pelagic BP. However, exploitation of benthic OC probably is suboptimal because of nutrient limitation (primarily by inorganic P) of BP.
\end{abstract}

Key words: sediment, benthic algae, organic carbon, bacterioplankton production, clear-water lake.

Benthic and pelagic habitats are major parts of lake ecosystems. Transfer of elements and energy between these habitats occurs both downward (sedimentation and biological uptake from the water column by benthic organisms) and upward (nutrient release, gas diffusion, resuspension, and feeding of pelagic organisms on benthic resources). Primary production (PP) can take place in both habitats. Whole-lake PP often is dominated by benthic algal production in shallow clear-water lakes, whereas pelagic PP dominates in eutrophic deep clear-water lakes (Ask et al. 2009a, Vadeboncoeur et al. 2008).

Heterotrophic bacteria also constitute an important resource for higher trophic levels, especially in unproductive clear-water and humic lakes (Jansson et al. 2007). In humic lakes, bacterial production (BP) often greatly exceeds $\mathrm{PP}$, so a large part of $\mathrm{BP}$ probably is supported by allochthonous organic $\mathrm{C}$

\footnotetext{
${ }^{4}$ E-mail addresses: patriciar@ege.fcen.uba.ar

5 jenny.ask@emg.umu.se

${ }^{6}$ catherine.hein@emg.umu.se

7 mats.jansson@emg.umu.se

8 jan.karlsson@emg.umu.se
}

(OC; Faithfull et al. 2011). In clear-water lakes, where input of allochthonous OC is low, pelagic BP can exceed pelagic PP (Karlsson et al. 2001), so the C support for pelagic BP must have come from allochthonous sources or from the sediment.

The effects of allochthonous OC on pelagic BP are well studied (Jansson et al. 2000, Lennon and Pfaff 2005, Kritzberg et al. 2006), but the extent to which OC from benthic algae supports pelagic BP is less understood. Sediments in clear-water lakes release OC to lake water (Jansson 1979, Karlsson and Säwström 2009), and this release is mediated by epipelic algae (Jansson 1980, Kaplan and Bott 1982, Hopkinson et al. 1998). Bacterioplankton use OC from benthic algae (Kamjunke et al. 2006). Thus, benthic algae may support a significant portion of pelagic BP in shallow clear-water lakes. Growth of bacterioplankton in lakes may be limited by inorganic nutrients or constrained by OC (Vadstein 2000, Faithfull et al. 2011). Moreover, bacterial uptake of OC from different sources, including benthic algal exudates, may be hampered by low inorganic nutrient availability in the pelagic habitat.

We carried out a series of experiments to test 3 hypotheses: 1) epipelic algae release OC to lake water, 
2) inorganic nutrient limitation restricts bacterioplankton consumption of OC in lake water, 3) algal OC and nutrient addition will result in a moderate stimulation of pelagic BP in lake water in contact with growing benthic algae. We carried out the experiments in the laboratory and in one small clear-water lake in northern Sweden.

\section{Methods}

\section{Study area}

Lake 6 is a small (5.2 ha), subarctic, clear-water lake in northern Sweden (lat $68^{\circ} 10^{\prime} 18^{\prime} \mathrm{N}$, long $19^{\circ} 49^{\prime} 34^{\prime \prime} \mathrm{E}$, $445 \mathrm{~m}$ asl) with a maximum depth of $4.4 \mathrm{~m}$ and a mean depth of $1.7 \mathrm{~m}$ (Karlsson and Byström 2005). The lake has a soft, highly organic bottom primarily covered by benthic diatoms and cyanobacteria. In 2010, we conducted 2 short-term laboratory experiments (June and July) with water and sediments from the lake and 1 field experiment (July) in mesocosms installed in the lake. We detected no thermal stratification (temperature change $>0.5^{\circ} \mathrm{C} / \mathrm{m}$ depth) in the shallow area of the lake where the experiments were conducted (depth $<1.5 \mathrm{~m}$ ), so we treated the water samples as homogeneous and representative of the water column. Lake water temperature ranged from 13.1 to $14.5^{\circ} \mathrm{C}$ during the study.

\section{Laboratory experiment 1}

We used ${ }^{14} \mathrm{C}$ as a tracer to estimate the release of OC from the benthic algae to the overlying water. We collected a set of 8 sediment cores $(6.4 \mathrm{~cm}$ diameter $)$ with benthic algae and minerogenic sediment (height $\sim 6$ and $4 \mathrm{~cm}$, respectively) and overlying water (height $\sim 15 \mathrm{~cm}$ ) from the lake at $\sim 1 \mathrm{~m}$ depth. We placed the cores in a climate chamber at lake temperature and at a light level of $110 \mu \mathrm{mol}$ photons $\mathrm{m}^{-2} \mathrm{~s}^{-1}$. This value was optimal because it exceeds the irradiance level at the onset of photosynthetic light saturation for many freshwater algal taxa (Kirk 2011). We waited $3 \mathrm{~h}$ to allow potentially disturbed sediment to settle (we did not observe any perturbation) before we removed the overlying water until $1 \mathrm{~cm}$ of water remained above the sediments. To label benthic algae, we added the ${ }^{14} \mathrm{C}$ tracer $(740 \mathrm{kBq}$ of $\mathrm{NaH}^{14} \mathrm{CO}_{3}$; Perkin-Elmer Inc., Waltham, Massachusetts) as slowly and evenly as possible to the water above the sediment with a micropipette. We filtered the removed water through precombusted $\left(400^{\circ} \mathrm{C}, 3 \mathrm{~h}\right)$ glass-fiber filters $(0.7-\mu \mathrm{m}$ nominal pore size; Whatman GF/F, Maidstone, UK) to remove large phytoplankton and grazers. Two hours after labelling the sediments, we carefully replaced the filtered water on the core.
We incubated 4 cores in optimum light levels and 4 cores in darkness with their tops open in climate chambers for $48 \mathrm{~h}$. We stirred the water overlying the sediments manually with a glass rod every $8 \mathrm{~h}$. Treatments under optimal light conditions represented OC release rates from benthic algae, whereas treatments in the dark represented baseline levels of OC release without benthic algae production.

We took water samples from the cores with a 20-mL syringe after $0,16,24$, and $48 \mathrm{~h}$ to measure OC release from the sediment $\left({ }^{14} \mathrm{C}\right.$ activity, in $\left.\mathrm{Bq}\right)$. We measured ${ }^{14} \mathrm{C}$ activity by transferring $3-\mathrm{mL}$ subsamples to 20-mL scintillation vials and acidifying with $6 \mu \mathrm{L}$ of $6 \mathrm{M} \mathrm{HCl}$. We left the vials under a fume hood overnight without caps to permit evaporation of ${ }^{14} \mathrm{C}$-labelled dissolved inorganic C (DIC). We converted the ${ }^{14} \mathrm{C}$ release to $C$ units as:

$$
\text { OC release rate }=1.06\left(\mathrm{O}^{14} \mathrm{C}\right)(\mathrm{DIC}) / 48\left(\mathrm{NaH}^{14} \mathrm{CO}_{3 \mathrm{ADD}}\right)
$$

where $\mathrm{O}^{14} \mathrm{C}$ is the total labelled $\mathrm{OC}$ released to the water column (dark values were subtracted from corresponding light values), 1.06 is the isotopic discrimination factor $\left({ }^{14} \mathrm{C}\right.$ is assimilated $\sim 6 \%$ more slowly than ${ }^{12} \mathrm{C}$; Wetzel and Likens 2000), DIC is the dissolved inorganic $\mathrm{C}$ in the water above the sediments, $\mathrm{NaH}^{14} \mathrm{CO}_{3 \mathrm{ADD}}$ is the amount of ${ }^{14} \mathrm{C}$ added at the beginning of the experiment, and $48 \mathrm{~h}$ is the time of incubation. We estimated the amount of labelled OC in the sediments as $\%$ added ${ }^{14} \mathrm{C}$ that was not retrieved in the water, assuming negligible losses of the initial ${ }^{14} \mathrm{C}$ to the atmosphere because of the circumneutral $\mathrm{pH}$ of lake water (Karlsson et al. 2001) and the fact that lake water was not supersaturated with $\mathrm{CO}_{2}$ (Karlsson et al. 2002).

\section{Laboratory experiment 2}

We conducted a short-term experiment with water collected from above the sediments to assess the limiting factors for pelagic PP and BP in Lake 6. We applied 4 treatments with 4 replicates each to $500 \mathrm{~mL}$ of water in 1-L bottles: $\mathrm{C}$ (1 $\mathrm{mg} \mathrm{C} / \mathrm{L}$ as glucose), $\mathrm{N}\left(300 \mu \mathrm{g} \mathrm{N} / \mathrm{L}\right.$ as $\left.\mathrm{NH}_{4} \mathrm{NO}_{3}\right), \mathrm{P}(20 \mu \mathrm{g} \mathrm{P} / \mathrm{L}$ as $\mathrm{Na}_{3} \mathrm{PO}_{4} \cdot 12 \mathrm{H}_{2} \mathrm{O}$ ), and control (ctrl no addition). Two days later, we collected more water from the lake and ran the combined additions of $\mathrm{N}+\mathrm{P}$ and $\mathrm{C}+\mathrm{N}+\mathrm{P}$ (molar ratio 129:22:1) and a control. Pelagic BP and PP did not differ between the controls from the 2 sampling occasions ( $t$-tests, $p>0.05$ ) and the experimental conditions were the same, so we pooled the data and averaged the controls.

We incubated the experimental bottles at lake temperature and optimum light conditions and shook 
them at 8 -h intervals. After $3 \mathrm{~d}$, we used the ${ }^{14} \mathrm{C}$ method (Schindler et al. 1972) as described in Karlsson et al. (2002) to measure pelagic PP (dissolved and particulate OC). We filled $43-\mathrm{mL}$ plastic tubes with water from each bottle ( 3 tubes/bottle), added $20 \mu \mathrm{L}$ of $\mathrm{NaH}^{14} \mathrm{CO}_{3}(3.7 \mathrm{MBq} / \mathrm{mmol})$, and incubated the tubes for $4 \mathrm{~h}$ in climate chambers in light (2 tubes / bottle) and dark conditions (1 tube/bottle). We terminated incubations by acidifying $5 \mathrm{~mL}$ of each sample with $50 \mu \mathrm{L}$ of $1 \mathrm{M} \mathrm{HCl}$. We added scintillation liquid (10 mL; Optiphase HiSafe 3, Perkin-Elmer) to the samples and measured the ${ }^{14} \mathrm{C}$ activity in a Beckman LS 6500 scintillation counter (BeckmanCoulter, Fullerton, California). We measured sample DIC from $4 \mathrm{~mL}$ of water acidified with $20 \mu \mathrm{L}$ of $6 \mathrm{M}$ $\mathrm{HCl}$ in a gas chromatograph (CP4900; Varian, Palo Alto, California).

We used the ${ }^{3} \mathrm{H}$-leucine incorporation method described by Smith and Azam (1992) to estimate pelagic BP. We incubated triplicate 1.2-mL samples from each bottle in the dark for $1 \mathrm{~h}$ in Eppendorf tubes. One of 3 samples served as a control, so we added $65 \mu \mathrm{L}$ of $100 \%$ trichloroacetic acid (TCA) to kill bacterioplankton before adding the radioisotope. We added ${ }^{3} \mathrm{H}$-leucine (5.85 TBq/mmol; Perkin-Elmer) to each tube for a final concentration of $50 \mathrm{nM}$. We ended the incubation by adding $65 \mu \mathrm{L}$ of $100 \%$ TCA. We then vortexed samples, centrifuged them for $10 \mathrm{~min}$ at $12,000 \mathrm{rpm}$, and discarded the supernatant. We rinsed samples twice by adding $1.2 \mathrm{~mL}$ of $5 \%$ TCA, vortexing, centrifuging, and discarding the supernatant. Last, we added $1.2 \mathrm{~mL}$ of scintillation liquid (Optiphase HiSafe 3, Perkin-Elmer) and measured ${ }^{3} \mathrm{H}$ activity with a Beckman LS 6500 scintillation counter. We converted ${ }^{3} \mathrm{H}$-leucine incorporation rates to $C$ units with the method of Simon and Azam (1989).

\section{Field experiment}

We used a mesocosm experiment to assess effects of benthic OC on pelagic production in the natural environment. We placed 8 transparent plastic enclosures (mesocosms) with wooden frames $(1.2 \times 1.2 \times 1.5 \mathrm{~m}$ tall) close to shore at $\sim 1 \mathrm{~m}$ depth. The enclosures were $1.5 \mathrm{~m}$ high to allow us to ground them in the sediment and still have them reach well above the water surface. Average depth and volume of the mesocosms were $0.7 \mathrm{~m}$ and $960 \mathrm{~L}$, respectively. We buried the plastic walls of 4 mesocosms in the sediment (benthic + pelagic system, treatment = "with sediment"), whereas we enclosed the bottoms of the other 4 mesocosms with the same plastic material used for the sides to exclude the sediment and the associated benthic algae (pelagic system, treatment $=$ "without sediment").

We began sampling $1 \mathrm{~d}$ after installing the mesocosms (day 1) to allow resettling of disturbed sediment, which we minimized by working from a boat. The experiment lasted $17 \mathrm{~d}$. One of the enclosures with sediment was lost at the beginning of the experiment. During the experiment, we observed no signs of biofilm colonization on the mesocosms' walls, and in similar short-term mesocosm experiments in unproductive lakes (Vrede 1996, Jansson et al. 2006), effects of wall films on processes in the water column were negligible.

We used a Ruttner sampler to collect 1.5-L water samples from each mesocosm every $4 \mathrm{~d}$. We transported the water to the laboratory in darkness and used the methods described above to analyze it within $2 \mathrm{~h}$ for pelagic BP and PP. We filtered $20 \mathrm{~mL}$ samples for dissolved organic $\mathrm{C}$ (DOC) analyses through precombusted $\left(400^{\circ} \mathrm{C}, 3 \mathrm{~h}\right)$ glass-fiber filters (Whatman GF/F). We preserved the filtrate with $40 \mu \mathrm{L}$ of $6 \mathrm{M} \mathrm{HCl}$ and analyzed it within $48 \mathrm{~h}$ in a Shimadzu TOC-5000 total C analyzer (Shimadzu, Kyoto, Japan).

\section{Statistical analyses}

Laboratory experiment 1.-We used repeated measures analysis of variance (rmANOVA) to test the effects of light (light vs dark), time, and their interaction on ${ }^{14} \mathrm{C}$ release from sediments to the overlying water. The interaction between factors was significant, so we ran multiple comparisons (Bonferroni test) to identify significant differences between light and dark treatments at each time and to identify differences within treatments over time.

Laboratory experiment 2.-We used 1-way ANOVA to test for differences in pelagic $\mathrm{BP}$ and $\mathrm{PP}$ among the 5 treatments $(\mathrm{C}, \mathrm{N}, \mathrm{P}, \mathrm{N}+\mathrm{P}, \mathrm{C}+\mathrm{N}+\mathrm{P})$ and the control. We used Tukey post hoc comparisons to identify treatments that were significantly different from the others. We $\log (x)$-transformed PP to meet assumptions of normality and homogeneity of variance.

Field experiment.-We used rmANOVA to test for effects of sediment (with vs without), time (5 dates), and the sediment $\times$ time interaction on $\mathrm{PP}, \mathrm{BP}, \mathrm{PP} / \mathrm{BP}$, and DOC. When the sediment $\times$ time interaction was significant, we used multiple comparisons testing (Bonferroni test) to identify significant differences between sediment treatments on each date and to identify differences over time within each sediment treatment. If the interaction between factors was not significant (BP), we used Tukey post hoc comparisons to identify which treatments and dates were significantly different from the others (Zar 2010). We ran all statistical tests in SPSS for Windows (version 15; SPSS, Chicago, Illinois). 
TABLE 1. Mean $( \pm S D){ }^{14} \mathrm{C}$ activity and percentage of ${ }^{14} \mathrm{C}$ added to the sediment retrieved as organic $\mathrm{C}$ in the water and the sediment after $48 \mathrm{~h}$ in light and dark incubations. Repeated measures analysis of variance result: light effect, $\mathrm{df}=1, F=97.3, p=$ 0.0001; time, $\mathrm{df}=3, F=9.05, p=0.001$; light $\times$ time, $\mathrm{df}=3, F=8.74, p=0.001$.

\begin{tabular}{ccccc}
\hline \hline Light condition & $\begin{array}{c}{ }^{14} \mathrm{C} \text { added to the } \\
\text { sediment }(\mathrm{Bq})\end{array}$ & $\begin{array}{c}{ }^{14} \mathrm{C} \text { released to the } \\
\text { water after } 48 \mathrm{~h}(\mathrm{~Bq})\end{array}$ & ${ }^{14} \mathrm{C}$ in the water $(\%)$ & ${ }^{14} \mathrm{C}$ in the sediment $(\%)$ \\
\hline Light & $74 \times 10^{4}$ & $44 \pm 3$ & $5.9 \times 10^{-3}$ & $68 \times 10^{-3}$ \\
Dark & $74 \times 10^{4}$ & $13 \pm 5.4$ & $1.7 \times 10^{-3}$ & $2.8 \times 10^{-3}$ \\
\hline
\end{tabular}

\section{Results}

\section{Laboratory experiment 1}

${ }^{14} \mathrm{C}$ activity in the water overlying the sediments increased during the experiment (Table 1) showing a net flux of labelled OC from the sediments to the water. The increase was greater in the light than in darkness (48 h, $p<0.001$; light treatment, $p=0.03$ ). The OC release rate from the sediments attributed to benthic algal photosynthesis (light - dark) was $\sim 45.4 \mathrm{ng} \mathrm{C} \mathrm{m} \mathrm{m}^{-2}$.

\section{Laboratory experiment 2}

Pelagic BP increased when $\mathrm{P}$ was added alone or in combination with $\mathrm{N}$ and reached maximum values when $\mathrm{P}$ was supplied in combination with $\mathrm{N}$ and $\mathrm{C}$.
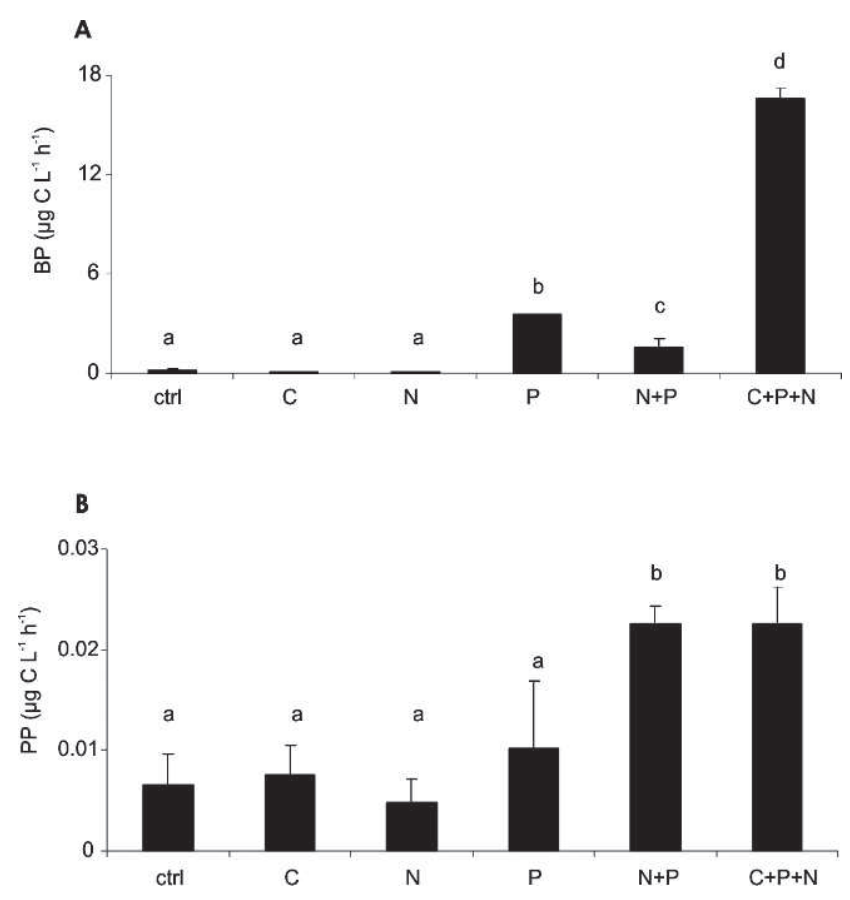

FIG. 1. Mean (+1 SD) bacterioplankton production (BP) (A) and primary production (PP) (B) in lake water in laboratory experiment 2. $\mathrm{Ctrl}=$ control, $\mathrm{C}=$ glucose addition, $\mathrm{N}=\mathrm{N}$ addition, $\mathrm{P}=\mathrm{P}$ addition. Bars with the same letters are not significantly different $(p>0.05)$.
Addition of $\mathrm{C}$ or $\mathrm{N}$ alone did not affect pelagic $\mathrm{BP}$, a result suggesting that pelagic $\mathrm{BP}$ was limited primarily by $\mathrm{P}$, with $\mathrm{C}$ as a secondary limiting nutrient (1way ANOVA, $F_{5,22}=133.4, p<0.0001$; Fig. 1A). Pelagic PP (mean \pm SD $=0.012 \pm 0.008 \mu \mathrm{g} \mathrm{C} \mathrm{L}^{-1} \mathrm{~h}^{-1}$ ) was consistently lower than pelagic BP $(3.2 \pm 6 \mu \mathrm{g} C$ $\mathrm{L}^{-1} \mathrm{~h}^{-1}$ ) and increased relative to the control only when $\mathrm{N}$ and $\mathrm{P}$ were added together (1-way ANOVA, $F_{5,21}=15.2, p<0.0001$, Fig. $\left.1 \mathrm{~B}\right)$, a result indicating colimitation by these nutrients.

\section{Field experiment}

Pelagic BP was lower in mesocosms without than with sediment (Fig. 2A) and changed significantly over time (Table 2). Pelagic BP was significantly higher on day 13 than on other sampling dates $(p<$ $0.05)$. The sediment $\times$ time interaction significantly affected PP (Table 2, Fig. 2B). The magnitude of this interaction was negligible in mesocosms with sediment $(p>0.05)$. In mesocosms without sediments, PP decreased significantly between days 13 and $17(p=$ 0.03). The pelagic PP/BP quotient was always $<0.5$ and did not differ over time within sediment treatments (without sediment, $p=0.38$; with sediment, $p=0.74)$. The quotient differed between sediment treatments only on day $13(p=0.03)$.

DOC concentration was higher in mesocosms with sediment $(4.41 \pm 0.61 \mathrm{mg} / \mathrm{L})$ than without sediment $(4.12 \pm 0.44 \mathrm{mg} / \mathrm{L})$ (Fig. $2 \mathrm{C})$. The sediment $\times$ day interaction was significant (Table 2), and differences between treatments were detected on days $9(p=$ $0.03)$ and $17(p=0.002)$.

\section{Discussion}

Our ${ }^{14} \mathrm{C}$ labeling experiment demonstrated that the sediment took up labeled DIC, accumulated labeled OC, and released labeled OC to the overlying water when the experimental clear-water systems were exposed to light (Table 1). We also showed that sediments stimulated BP in the water above the sediment (Fig. 2A). Therefore, we attribute the high BP to the release of $\mathrm{OC}$ from benthic algae. These results indicate that organic exudates from growing epipelic 

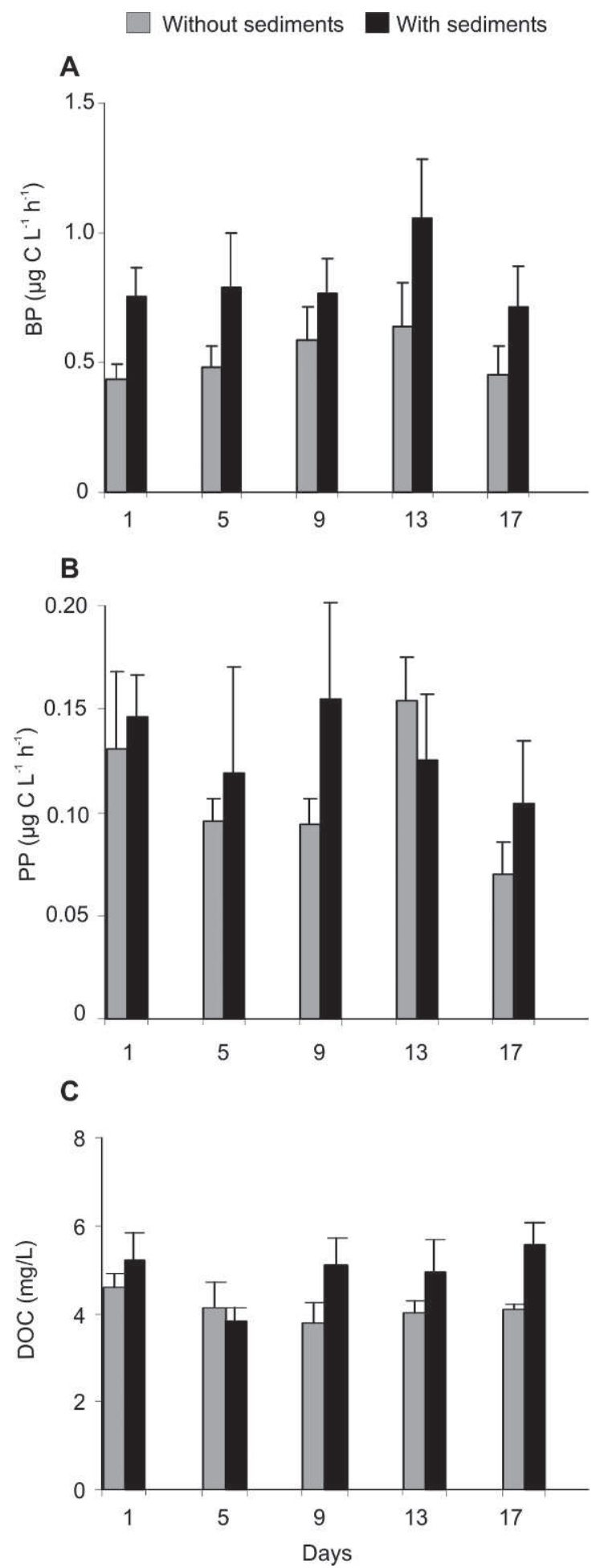

FIG. 2. Mean (+1 SD) bacterioplankton production (BP) (A), primary production (PP) (B), and dissolved organic C (DOC) concentration $(C)$ in field mesocosms without and with sediments. algae had positive effects on the growth of bacterioplankton and that this effect was hampered by inorganic nutrient limitation of BP (Fig. 1A).

The ${ }^{14} \mathrm{C}$ labeled OC in the water constituted $\sim 10 \%$ of the net accumulation of $\mathrm{O}^{14} \mathrm{C}$ in the surface sediment (Table 1), and the field experiment demonstrated substantial changes in the dissolved organic matter pool of the water when OC release from sediments was prevented. Our data do not permit firm conclusions about the composition and bioavailability of released OC, but a reasonable assumption is that these exudates are labile and can be exploited by heterotrophic bacteria (Kamjunke et al. 2006). Assimilation of exudates on the sediment surface and respiration of exudates in the water column during the experiment mean that the release of $\mathrm{OC}$ by benthic algae exceeded the $10 \%$ we retrieved as OC in the water column. For our purposes, we can neglect possible consumption of DOC in the sediment and focus on DOC that is released to the lake water. Assuming that heterotrophic bacterioplankton metabolize all of the OC released to the water column with a bacterial growth efficiency (BGE) of 20\% (del Giorgio and Cole 1998), the release would be $5 \times$ higher than the $\mathrm{OC}$ accumulation, a result implying that release to the water column is $50 \%$ of the net accumulation in the sediment. Other investigators have shown that as much as $80 \%$ of the $\mathrm{C}$ accumulated in benthic algae can end up in organic exudates that can be metabolized in the sediment and the water above the sediment (Perkins et al. 2001, Wolfstein et al. 2002, Stal 2003).

The possible stimulatory effect of benthic algal exudates on pelagic BP has not been addressed quantitatively in other studies. The low PP relative to $\mathrm{BP}$ in the lake water (Figs 1A, B, 2A, B) clearly shows that phytoplankton could support only a minor part of the bacterioplankton C demand. Based on results of studies in similar lakes in the area, pelagic PP generally sustains only $\sim 20 \%$ of bacterioplankton C demand (Ask et al. 2009b). Thus, the missing $C$ must be derived from OC released from the sediments or from OC imported from the catchment. In brownwater lakes the input of terrestrial $C$ is high, but researchers have questioned whether recalcitrant terrestrial OC alone could sustain the relatively high bacterial $\mathrm{C}$ demand in many clear-water lakes (Karlsson et al. 2002, Kritzberg et al. 2004).

We combined our results (OC exudates) with results from studies of summer rates of $\mathrm{PP}$ and $\mathrm{BP}$ in water and sediments in other shallow clear-water lakes (Ask et al. 2009b) to assess the possible pelagic bacterial use of OC released by benthic algae. We assumed that 10 (minimum) to 50\% (maximum) of net 
TABLE 2. Repeated measures analysis of variance results for bacterial production (BP), primary production (PP), the PP/BP ratio, and dissolved organic $\mathrm{C}$ (DOC) concentration in field mesocosms incubated for $17 \mathrm{~d}$ with and without sediment. Bold indicates $p<0.05$.

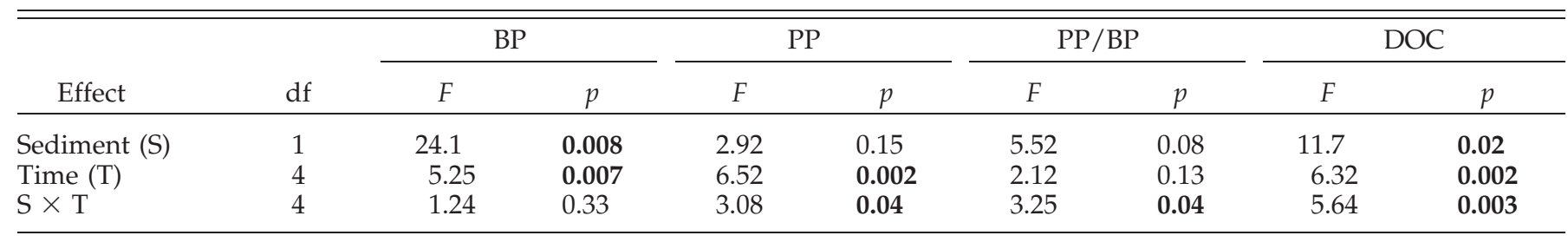

benthic PP could be released to the lake water as labile OC, which implies a summer mean input to lake water from sediments $\approx 10-50 \mathrm{mg} \mathrm{C} \mathrm{m}^{-2} \mathrm{~d}^{-1}$. If we assume a BGE of 20\% (del Giorgio and Cole 1998), then 2 to $10 \mathrm{mg} \mathrm{C} \mathrm{m}^{-2} \mathrm{~d}^{-1}$ could be used for BP. This range corresponds to $\sim 20$ to $100 \%$ of total $\mathrm{BP}$ or 25 to $120 \%$ of the bacterioplankton not covered by phytoplankton production reported by Ask et al. (2009b). These simple estimates imply that the benthic OC release has the potential to sustain a significant share of the bacterioplankton production in shallow clearwater lakes like our study lake. These results are in agreement with a recent study of winter metabolism in the lake in which OC released from epipelic algae supported, presumably via heterotrophic bacterioplankton, a major part of zooplankton growth (Karlsson and Säwström 2009). The process is an example of how microbial loops can function across habitats, where heterotrophic bacteria in the pelagic habitat exploit autotrophic OC generated in the benthic habitat.

The release of benthic OC can affect overall lake metabolism through its effects on lake-water nutrient stoichiometry, nutrient limitation in bacterioplankton and phytoplankton, and ultimately the balance between phytoplankton and bacterioplankton production. Bacterioplankton use of benthic OC was suboptimal because of nutrient limitation (Fig. 1A). Use of benthic algal exudates should increase the bacterioplankton demand for $\mathrm{N}$ and $\mathrm{P}$ with secondary effects on phytoplankton nutrient limitation. Consequently, the OC release could affect C:nutrient resource stoichiometry of the lake water and increase the competition for nutrients between bacterioplankton and phytoplankton. In laboratory and whole-lake experiments, introduction of organic substrates favors bacterial growth at the expense of phytoplankton growth (Currie and Kalff 1984, Blomqvist et al. 2001). Thus, benthic OC release may repress pelagic PP, which could help explain why benthic PP often is an order of magnitude higher than pelagic PP in small clear-water lakes (Vadeboncoeur et al. 2003, Ask et al. $2009 \mathrm{~b}$ ) and why bacterioplankton production is several times higher than phytoplankton production in clear-water lakes (Karlsson et al. 2001, 2002).

\section{Acknowledgements}

We thank Marina Becher, Thomas Westin, and Tyler Logan for their help with the field and laboratory work. Financial support for PR to stay in Sweden was obtained through a fellowship from CONICET (Argentina) and a grant from the University of Buenos Aires (UBACyT X815). This study was financially supported by the Climate Impacts Research Centre (CIRC).

\section{Literature Cited}

Ask, J., J. Karlsson, L. Persson, P. Ask, P. Byström, and M. JANSSON. 2009a. Terrestrial organic matter and light penetration: effects on bacterial and primary production in lakes. Limnology and Oceanography 54:2034-2040.

Ask, J., J. Karlsson, L. Persson, P. Ask, P. Byström, and M. JANSSON. 2009b. Whole-lake estimates of carbon flux through algae and bacteria in benthic and pelagic habitats of clear-water lakes. Ecology 90:1923-1932.

Blomevist, P., M. Jansson, S. Drakare, A.-K. Bergström, AND L. BRYDSTEN. 2001. Effects of additions of DOC on pelagic biota in a clearwater system: results from a whole-lake experiment in northern Sweden. Microbial Ecology 42: 383-394.

CurRIE, D. J., AND J. KalfF. 1984. A comparison of the abilities of freshwater algae and bacteria to acquire and retain phosphorus. Limnology and Oceanography 29:298-310.

del Giorgio, P., and J. J. Cole. 1998. Bacterial growth efficiency in natural aquatic systems. Annual Review of Ecology and Systematics 29:503-541.

FAITHFULL, C. L., A.-K. BERGSTRÖM, AND T. VREDE. 2011. Effects of nutrients and physical lake characteristics on bacterial and phytoplankton production: a meta-analysis. Limnology and Oceanography 56:1703-1713.

Hopkinson, C. S., A. E. Giblin, R. H. GarRitT, J. Tucker, AND M. A. J. Hullar. 1998. Influence of the benthos on growth of planktonic estuarine bacteria. Aquatic Microbial Ecology 16:109-118.

JANSSON, M. 1979. Nutrient budgets and the regulation of nutrient concentrations in a small sub-arctic lake in northern Sweden. Freshwater Biology 9:213-231. 
JANSSON, M. 1980. Role of benthic algae in transport of nitrogen from sediment to lake water in a shallow clearwater lake. Archiv für Hydrobiologie 89:101-109.

Jansson, M., A.-K. Bergström, P. Blomevist, and S. Drakare. 2000. Allochthonous organic carbon and phytoplankton/bacterioplankton production relationships in lakes. Ecology 81:3250-3255.

Jansson, M., A.-K. BergströM, D. Lymer, K. VRede, AND J. KARLSSON. 2006. Bacterioplankton growth and nutrient use efficiencies under variable organic carbon and inorganic phosphorus ratios. Microbial Ecology 52:358-364.

Jansson, M., L. Persson, A. M. DE Roos, R. I. Jones, And L. J. TRANVIK. 2007. Terrestrial carbon and intraspecific sizevariation shape lake ecosystems. Trends in Ecology and Evolution 22:316-322.

Kamjunke, N., C. Bohn, AND J. GRey. 2006. Utilisation of dissolved organic carbon from different sources by pelagic bacteria in an acidic mining lake. Archiv für Hydrobiologie 3:355-364.

Kaplan, L. A., AND T. L. BOTT. 1982. Diel fluctuations of DOC generated by algae in a piedmont stream. Limnology and Oceanography 27:1091-1100.

Karlsson, J., AND P. BYstrÖM. 2005. Littoral energy mobilization dominates energy supply for top consumers in subarctic lakes. Limnology and Oceanography 50: 538-543.

Karlsson, J., M. Jansson, AND A. Jonsson. 2002. Similar relationships between pelagic primary and bacterial production in clearwater and humic lakes. Ecology 83: 2902-2910.

Karlsson, J., A. Jonsson, And M. Jansson. 2001. Bacterioplankton production in lakes along an altitude gradient in the subarctic north of Sweden. Microbial Ecology 42: 372-382.

Karlsson, J., And C. SÄwström. 2009. Benthic algae support zooplankton growth during winter in a clear-water lake. Oikos 118:539-544.

KIRK, J. T. O. 2011. Light and photosynthesis in aquatic ecosystems. $3^{\text {rd }}$ edition. Cambridge University Press, Cambridge, UK.

Kritzberg, E. S., J. J. Cole, M. L. Pace, W. Granéli, and D. L. BADE. 2004. Autochthonous versus allochthonous carbon sources of bacteria: results from whole-lake ${ }^{13} \mathrm{C}$ addition experiments. Limnology and Oceanography 49:588-596.

Kritzberg, E. S., J. J. Cole, M. M. Pace, and W. Granéli. 2006. Bacterial growth on allochthonous carbon in humic and nutrient-enriched lakes: results from whole-lake ${ }^{13} \mathrm{C}$ addition experiments. Ecosystems 9:489-499.

LenNon, J. T., AND L. E. Pfaff. 2005. Source and supply of terrestrial organic matter affects aquatic microbial metabolism. Aquatic Microbial Ecology 39:107-119.
Perkins, R. G., G. J. C. Underwood, V. Brotas, G. C. Snow, B. JESUS, AND L. RibeIRo. 2001. Responses of microphytobenthos to light: primary production and carbohydrate allocation over an emersion period. Marine Ecology Progress Series 223:101-112.

Schindler, D. W., R. V. Schmidt, And R. A. Reid. 1972. Acidification and bubbling as an alternative to filtration in determining phytoplankton production by the ${ }^{14} \mathrm{C}$ method. Journal of the Fisheries Research Board of Canada 29:1627-1631.

Simon, M., AND F. Azam. 1989. Protein content and protein synthesis rates of planktonic marine bacteria. Marine Ecology Progress Series 51:201-213.

Smith, D. C., AND F. Azam. 1992. A simple, economical method for measuring bacterial protein synthesis rates in seawater using ${ }^{3} \mathrm{H}$-leucine. Marine Microbial Food Webs 6:107-114.

Stal, L. J. 2003. Microphytobenthos, their extracellular polymeric substances, and the morphogenesis of intertidal sediments. Geomicrobiology Journal 20:463-478.

Vadeboncoeur, Y., E. Jeppesen, M. J. Vander Zanden, H. H. Schierup, K. Christoffersen, And D. M. Lodge. 2003. From Greenland to green lakes: cultural eutrophication and the loss of benthic pathways in lakes. Limnology and Oceanography 48:1408-1418.

Vadeboncoeur, Y., G. Peterson, M. J. Vander Zanden, And J. KALFF. 2008. Benthic algal production across lake size gradients: interactions among morphometry, nutrients and light. Ecology 89:2542-2552.

VADSTEIN, O. 2000. Heterotrophic, planktonic bacteria and cycling of phosphorus-phosphorus requirements, competitive ability, and food web interactions. Pages 115-167 in B. Schink (editor). Advances in microbial ecology. Kluwer Academic/Plenum Publishers, New York.

VREDE, K. 1996. Regulation of bacterioplankton production and biomass in an oligotrophic clearwater lake-the importance of the phytoplankton community. Journal of Plankton Research 18:1009-1032.

Wetzel, R. G., AND G. E. LiKens. 2000. Limnological analyses. $3^{\text {rd }}$ edition. Springer, New York, USA.

Wolfstein, K., J. F. C. DE Brouwer, and L. J. Stal. 2002. Biochemical partitioning of photosynthetically fixed carbon by benthic diatoms during short-term incubations at different irradiances. Marine Ecology Progress Series 245:21-31.

ZAR, J. H. 2010. Biostatistical analysis. $5^{\text {th }}$ edition. Prentice Hall, Upper Saddle River, New Jersey.

Received: 13 January 2012 Accepted: 6 November 2012 